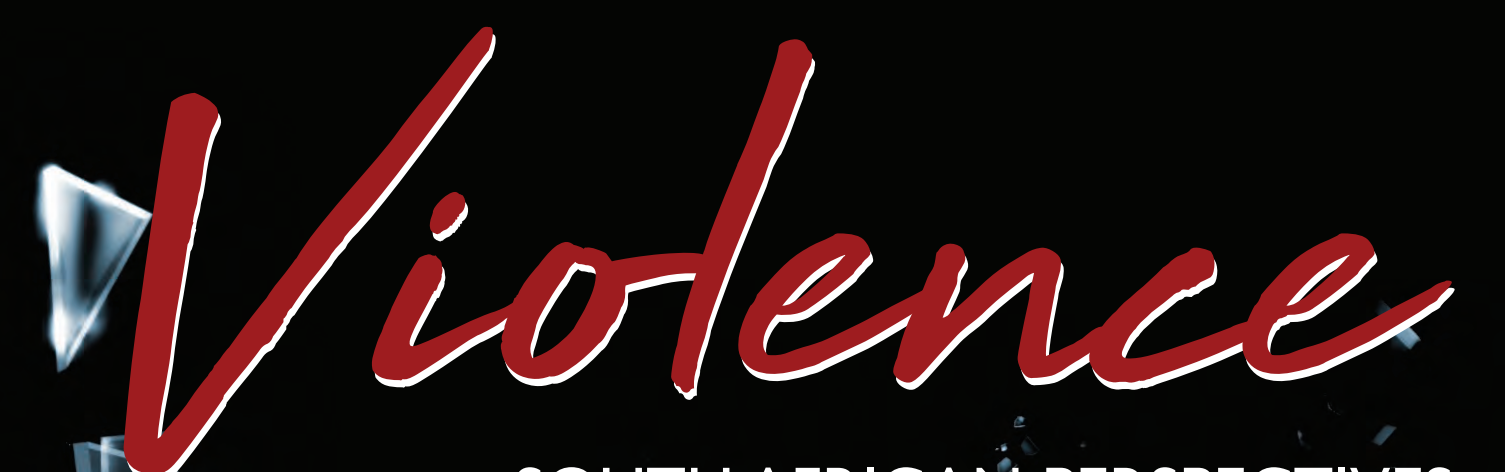

SOUTH,AFRICAN PERSPECTIVES

$\rightarrow$

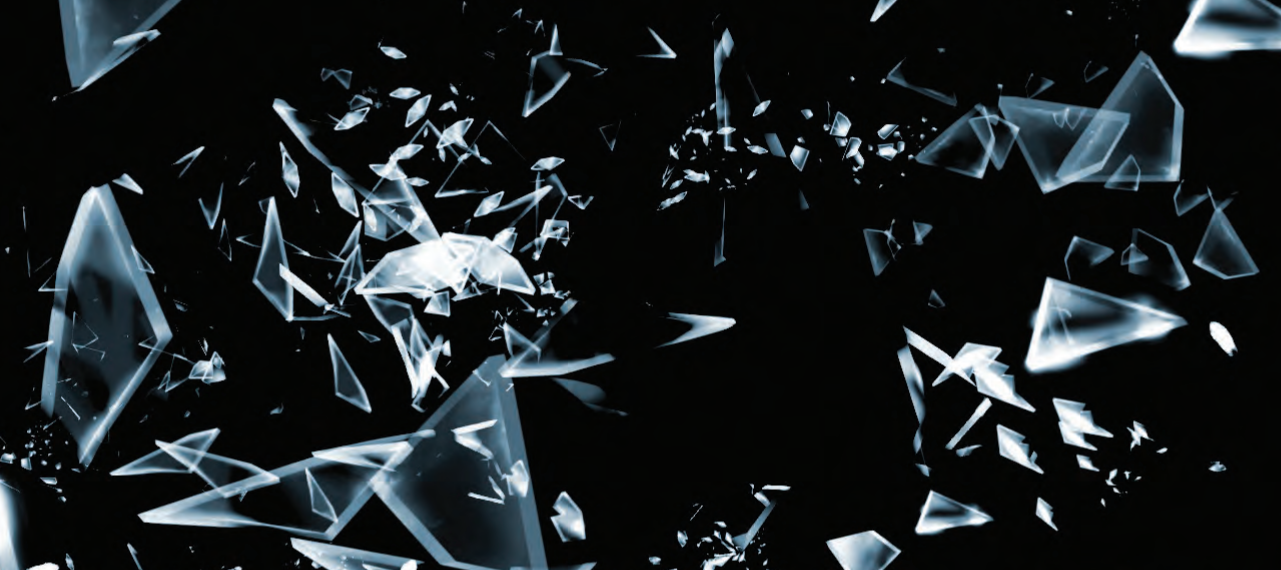

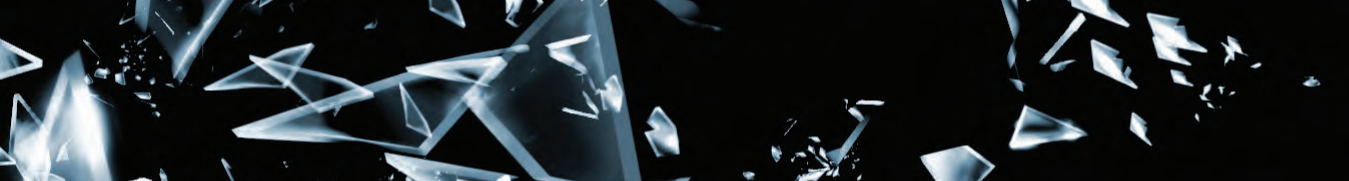

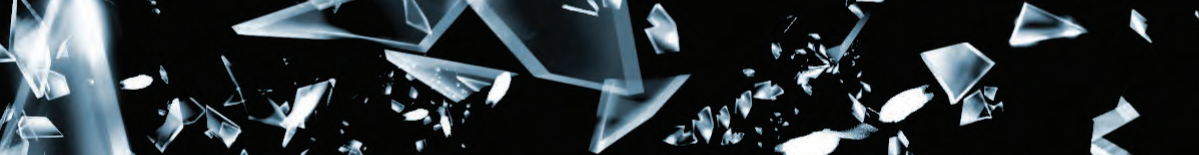

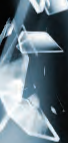

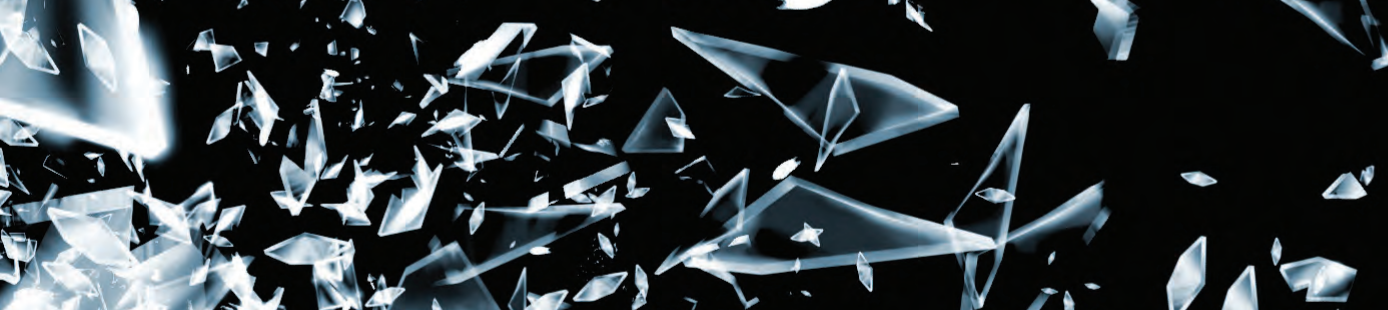

,

a 4 < 6

QX

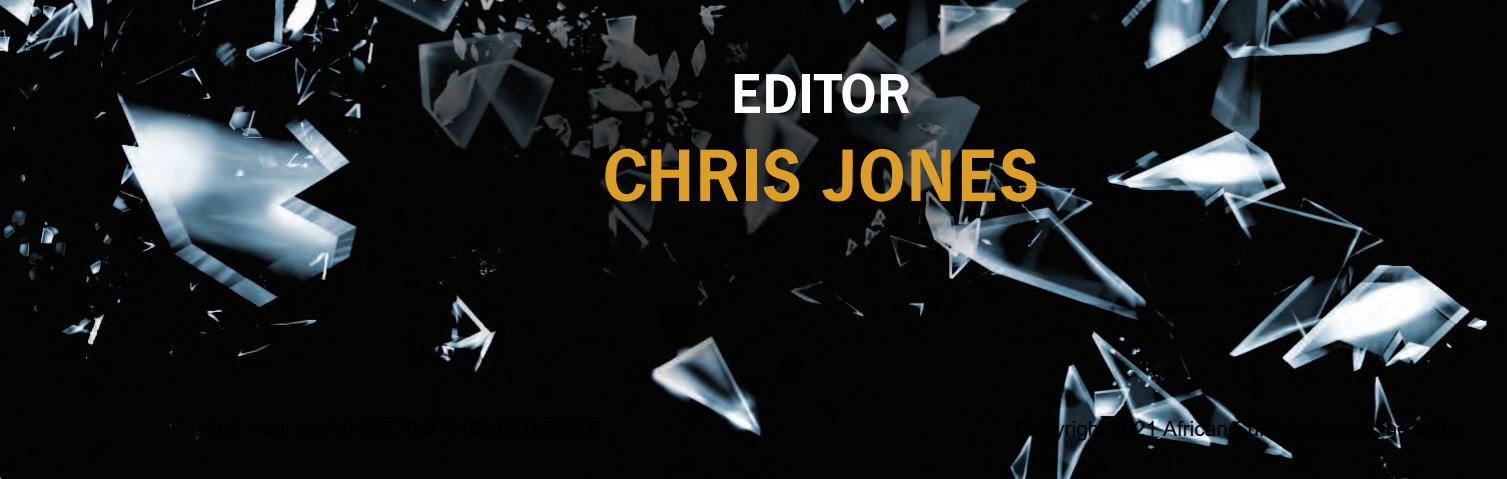




\section{LESBIAN DIS/APPEARANCES: EPISTEMIC VIOLENCE AGAINST INTERNAL DISSIDENTS IN THE FORMATION OF AFRIKANER IDENTITY}

Christi van der Westhuizen

\section{Keywords}

Afrikaner nationalism; dissidence; lesbianism; South Africa

\section{INTRODUCTION}

As with all national identities, the history of Afrikaner nationalism, and hence of Afrikaner identity, is a history of the violences of exclusion and inclusion. 'The Afrikaner' was not only aimed at the exclusion of racialised and ethnicised others but involved a mishmash of social categories of differentiation. The significance of gender and sexual disciplining at the intersection with race becomes apparent when the focus is primed on the internal others of Afrikaner identity. As with all nationalisms, the moulding of women in accordance with an ideal model that can ensure the reproduction of the nation, or volk in this case, is all-important. Without female subjects obedient to the proposed ideal femininity, there is no nation. Hence, the focus on women as biological and social reproducers tasked with maintaining the mores that will keep the boundaries of the volk intact. Nationalisms frequently have an idealised model of womanhood in the form of the 'mother of the nation'. The volksmoeder, Afrikaner nationalism's equivalent, is remarkably adaptive (Van der Westhuizen 2017).

The contradictory trope of the volksmoeder reveals an intense gender struggle as formative of the terms of nascent Afrikaner nationalism, determining the content of cultural representations and access to agency by female and male members of the volk. The National Party's (NP) ascendance to controlling the levers of state in 1948 marks Afrikaner women's movement back into the home. The effective National Women's Parties had been absorbed into the male NP, and the fiery trade unionism associated with the women of the Garment Workers' Union was in the past (Vincent 1999; Brink 1990). Hence, the counterintuitive fact that Afrikaner women were more politically and publicly engaged in the first half of the 20th century than in the second half. Their 
redirection back into the home marks the triumph of patriarchal heteronormativity at the heart of Afrikaner identity. During apartheid, Afrikaner nationalist processes of remembering and un-remembering enforced the domestication of Afrikaner women by erasing Afrikaner women's public activism (Van der Westhuizen 2018).

This un-remembering is here read as a form of epistemic violence, given that this form of violence suppresses or excises alternative or dissident knowledges in the historical making of 'Afrikaner' identity. The silences over "Afrikaner women in Afrikaner historiography, as well as their absence in recent politics" amount to the "reproduction of amnesia in history" (Sherman 1998:116). This process is explored through the figure of the relatively little-known Dr Petronella 'Nell' van Heerden (26 April 1887 to 10 January 1975), both the first woman to open a practice as a medical doctor and to specialise as a gynaecologist in South Africa. At first glance, she seems a mere beneficiary of the early Afrikaner nationalist drive to include firstwave uplift feminists in the volksbeweging. However, her adoption of a dissident subject position that was leftist and resisted heteronormativity and other oppressive forms of power (Smit 2017:4; Steyn 1991:34) sets her apart. In making this argument, the chapter is structured as follows: after a short discussion of epistemic violence as directed at women and particularly lesbians, Trouillot's frame on silences in historymaking is applied to biographical texts on Van Heerden.

\section{Epistemic violence}

The excision of Afrikaner women and particularly dissident Afrikaner women from Afrikaner nationalist history is approached here through the concept of epistemic violence. Epistemes are systems of knowledge that orientate and determine how people make sense of their worlds and their selves, and therefore are deeply implicated in the organisation of power in oppressive or resistant formations. Hence Foucault's compound construction of 'power/knowledge' turning bodies into subjects. Knowledge has come under renewed scrutiny in the work of post-structural, postcolonial and decolonial thinkers. Pluralising the concept to 'knowledges' is to surface that knowledge is partial and situated, and thereby to problematise the western epistemic paradigm's projection of itself as universal, objective, and disembodied (Grosfoguel 2002).

Colonialism imposed a western epistemic frame of hierarchical binarisms, denoting superiority and inferiority (Grosfoguel 2002; Quijano 2000). According to Lugones (2007), colonialism violently introduced gender, giving rise to the modern/colonial gender system with gender imbricated with race and compulsory heterosexuality. Lugones distinguishes between a dark side that subjects colonised people to extreme violence and a light side that constructs white bourgeois 'men/women':

Sexual purity and passivity are crucial characteristics of the white bourgeois females who reproduce the class and the colonial and racial standing of bourgeois, white men. But equally important is the banning of white bourgeois 
women from the sphere of collective authority, from the production of knowledge, from ... the means of production. Weakness of mind and body are important in the reduction and seclusion of white bourgeois women from most domains of life ... The gender system is heterosexualist, as heterosexuality permeates racialized patriarchal control over production, including knowledge production, and over collective authority.

(Ibid:206)

What Lugones describes, applies optimally to Afrikaner women's evacuation from the public sphere. Van Heerden stands out as a primary transgressor of these prescriptions amongst her counterparts. The almost complete elision of Van Heerden from the Afrikaner nationalist archive speaks to more than the impossibility of women as agents of history. I have elsewhere fingered homophobia as one cause of Van Heerden's near-invisibility in the archive, due to both commission and omission in the form of active suppression in her lifetime and subsequent erasures (Van der Westhuizen 2020; see also Smit 2017 and Viljoen 2008). She was a woman who claimed access to "the sphere of collective authority" and to the production of knowledge in her writings and public activism.

Van Heerden's taking up of full-time farming radically undermined the notion of the "weakness of mind and body" inflicted on white bourgeois women. Erasing her from Afrikaner historiography was about removing the possibility of transgression, and then to strategically reintroduce the memory of her in ways that would affirm Afrikaner nationalist goals.

The deletions aimed at Van Heerden are reflective of the near non-existence of a lesbian archive in South Africa, even of white middle class women as the most privileged group amongst South African lesbians. Van Heerden's lesbian identity is of particular importance to her position as dissident. As female bodies outside of biological and social reproduction, lesbians are rendered necessarily unintelligible and are therefore expunged from the nationalist script. 'The lesbian' can have a disruptive effect on nationalism because of her radical otherness. The structure of heteronormativity involves a hierarchical sex dimorphism of man/woman that maps onto an unequal gender opposition masculine/feminine, followed by a shift from the homo alignment of sex and gender to prescribe heterosexuality in the form of male to female sexuality. Drawing on Butler, Lee-Lampshire (1999:3) writes that subjects that performatively indicate any alternative to the heteronormative frame could create a "chaotic dissonance" in the constitution of subjectivity. The ontological danger that a lesbian poses is also epistemological:

Beyond ... hair, gait, clothes, and gestures, her attention to other women must be disrupted and disabled for it signals the possibility that she is in a position to know something to which the performers [of heterosexual womanhood] have little access; other women who may recognize such attention as the intentional expression of desire and/or resistance could acknowledge or even reciprocate. 
Hence, the lesbian must be rendered something that does not exist; certainly, in the nationalist frame, she must be an impossibility. The multiple cuts to which Van Heerden was subjected in both life and in the archiving and narrativisation of her life, demonstrate the threat that an agentic woman - politically, sexually, epistemologically - presented to Afrikaner nationalism and to colonial patriarchal whiteness more broadly. In the next section, Trouillot's (1995) four phases of silencing in the making of history is applied to make sense of the un-remembering of Van Heerden as an exemplar of the internal domestication of dissidence within Afrikanerdom.

\section{DISCUSSIONS OF ARCHIVE: MULTIPLE CUTS}

Absence from history is "to be lost from the possible world of knowledge", writes Trouillot (1995:48) in his probe of the silences within the history of the Haitian war of independence. He regards presences and absences in the historical record and in the archives as "neither neutral [n] or natural". Indeed, silence is "an active and transitive process: one 'silences' a fact or an individual as a silencer silences a gun. One engages in the practice of silencing. Mentions and silences are thus active, dialectical counterparts of which history is the synthesis ... absence itself is constitutive of the process of historical production" (ibid:48-49). This fits with the theoretical analysis of Lee-Lampshire (1999) above that the iterative excision of the disruptive lesbian figure enables the repetition of the heteronormative formation of subjects, in this case, for the purpose of the entrenchment of Afrikaner nationalism and hence of apartheid.

Trouillot identifies four overlapping moments for silencing to occur in historical production (ibid:48-56). The first is the selection of artefacts and bodies to make an event into a fact. The second is the gathering and processing, as well as the exclusion and inclusion of the facts into documents and monuments to make an archive, and hence, a historically intelligible version of events. The third is when the facts are retrieved and turned into narratives, which are marked by differences in frequency of retrieval, and in the richness of facts and the weight attached to them. The fourth is the moment of attaching importance retrospectively, when 'history is made', which is the moment when the cumulative silences of the past three moments coagulate, needing interpretation to fill in the gaps. These four moments of the insertion of silences are read here as moments for cuts in historiography to legitimise official knowledges, in this case, Afrikaner nationalist mythmaking. As Sherman (1998:3) has it, Afrikaner nationalism attempted a totalising approach to construct a "finite reality" from which any deviation would be punishable by a severing of kinship.

The life story of Van Heerden - from induction to withdrawal and marginalisation, to provisional reincorporation in relation to Afrikaner nationalism (Van der Westhuizen 2020) - is mapped below according to these four moments. The inclusions and exclusions, as well as the verifications and abjections, are explored with reference to her significant relationships with four women: Gladys Steyn, Freddie Heseltine, 
Jean van der Poel and Rykie van Reenen. Despite the uses that Afrikaner nationalism could find for such an eminent and commanding subject, the cumulative silencing of Van Heerden's sexuality as her primary expression of dissidence overwhelmed her normative accomplishments to the extent of relative abjection until the democratic era.

This is read here as epistemic violence, with Van Heerden as an exemplar of those internal others excised from Afrikaner history, and therefore radically excluded from knowledge formative of Afrikaner subjectivities.

\section{Fact creation}

The facts of Van Heerden's life, as borne out by public and private records, are that she became the first woman in South Africa to qualify as a medical doctor, opening a practice in Harrismith in the then Orange Free State province in about 1916. She is also the first South African woman to become a gynaecologist, opening a practice in Cape Town upon her return from her studies in the Netherlands around 1924. Her working life ended as a sheep and cattle farmer near Harrismith in the early 1970s. In-between, she joined diggings in the Middle East and Southern Africa as an amateur archaeologist, served as a doctor in the defence force during World War II, wrote her autobiographies (Van Heerden 1962, 1965), as well as a genealogy of the Van Heerden family (Van Heerden 1969).

She was politically active during the 1920s to 1940s, serving in the NP's Cape Hoofbestuur (Top Management). She campaigned for women's suffrage, the Afrikaans language (writing the first Doctoral dissertation in Medicine in Afrikaans), and for the Republican cause in the Spanish civil war. Breaking from the NP in response to its fascist tendencies, she identified as a socialist and published a number of political pamphlets agitating against fascism and for workers' rights across racial boundaries (Van Heerden 1938a, 1938b). Van Heerden was also a prolific letter writer to newspapers, protesting against racism (Steyn 1992). She was an elite figure, in her long life moving amongst cultural and political notables, such as Emily Hobhouse, Marthinus Theunis Steyn, Rachel Isabella ‘Tibbie’ Steyn, Olive Schreiner, Havelock Ellis, Bertrand Russell, Aletta Jacobs, M.E. Rothmann, C.J. Langenhoven, Jan Smuts, D.F. Malan, E.M. Forster, Freya von Moltke, Helmuth von Moltke, Laurens van der Post, Pauline Smith, Rykie van Reenen, and Alba Bouwer.

As will be seen, these public facts were reclaimed as part of an Afrikaner nationalist discourse but eventually dissipated to the extent that, despite this illustrious life, Van Heerden is mostly unknown in South African and even Afrikaner society. The nonacademic popularly available narratives on her life, mostly only accessible with some difficulty, can be counted on one hand. These are an article series in the women's magazine, Sarie (Bouwer 1960), her two autobiographies, an insert in the SuidAfrikaanse Biografiese Woordeboek (South African Biographical Dictionary) (Van Reenen 1987), and an episode in a documentary television series (Dreyer 2013). This 
overall silencing, to be discussed as the third moment, has its genesis in the silences that enter the history-making process already at this stage. Censoring cuts occur in relation to Van Heerden's intimate relationships with four significant women in her life.

The earliest is Gladys Steyn, later to be admitted as South Africa's first female advocate and the first woman to be elected to the Free State provincial council. She was the daughter of the final president of the Boer republic of the Orange Free State. Van Heerden and Steyn probably knew each other as children. They met again as young adults in the Netherlands. Upon their return to South Africa in 1916, Van Heerden elected to start a general practice in Harrismith. The town is not far from Bloemfontein where Steyn had taken up the post of principal of an elite school for girls started by her parents. Steyn resigned as principal and moved in with Van Heerden. By 1921, the two women returned to Europe for studies: Steyn to pursue Law and Van Heerden Gynaecology. Later, as septuagenarian, Van Heerden described her and Steyn's five years together in Harrismith as the most joyful period of her life (1965:112). Tibbie Steyn expressed severe discontent about their relationship in letters to her close friend Hobhouse (Truter 1997:168-171).

Shortly after moving to Europe, Van Heerden joined up with Irene 'Freddie' Heseltine who she had met in the Cape earlier. They lived together from about 1922 until Van Heerden's death in 1975. Few facts are known about Heseltine apart from the 53 years she spent with Van Heerden. She was a canteen worker for the French Red Cross in World War I, and apparently related to an affluent British family, as the daughter of a stockbroker.

In the 1930s, Dr Jean van der Poel, an historian at the University of Cape Town and editor of Jan Smuts' papers (Hancock \& Van der Poel 1966-1973), became a constant presence in Van Heerden's life, seemingly until the latter's death in 1975. Apart from Van der Poel's academic works, few facts exist about her. Late in the 1950s, Rykie van Reenen met Van Heerden and also remained a meaningful part of Van Heerden's life until her passing. Van Reenen was the foremost female Afrikaans journalist of the latter part of the 20th century.

In her autobiographies, Van Heerden brings Steyn and Heseltine into her life story with casual references, but without explicitly naming her relationships with them. It is in the archives of those subjects to whom Van Heerden and others serve as constitutive outsides that most facts can be gleaned about her relationships with Steyn, Heseltine, Van der Poel, and Van Reenen, namely the archives of Tibbie Steyn and M.E. Rothmann and their interlocutors. The narratives that Tibbie Steyn, Rothmann, and others crafted about these women will be discussed in the section on moment three of silences entering the history-making process. Suffice to say here that a picture emerges of overlapping polyamorous relationships, at times triangular - to the intense distress of Van Heerden's detractors. 


\section{Fact assembly: Selective celebration}

Trouillot's second moment where silences appear in the making of history is when facts are gathered, or not, into documents towards rendering an archive. In Van Heerden's case, two instances can be discerned. First, historical figures' own omission, suppression, or destruction of facts. Second, omission, suppression, or destruction by chroniclers, researchers, and archivists. The most obvious mode of silencing in this moment by historical figures is the destruction of evidence and the elision of facts. Regarding destroying evidence, Van Heerden confirms in an undated letter that she and Heseltine had during the farming period of their lives destroyed their personal letters (ironically while reminiscing about their life together) (Van Heerden n.d.). As an identity rendered culturally unintelligible and persecuted within a heteronormative hegemony, self-erasure by lesbians is historically common (Freedman 1998).

Gladys Steyn's archive in the National Archives in the Free State province contains several biographical notes where she revisited, as an elderly woman, the circumstances of her becoming an advocate. Strikingly, in the one handwritten account, Gladys omitted her period in Harrismith completely and changed the date of her resignation as school principal from 1917 to 1919 (G. Steyn n.d. a). In another, she omitted the dates, Harrismith, and Van Heerden, but still indicated that she had resigned as principal to study (G. Steyn n.d. b). In yet another autobiographical note, Gladys repeated this but mentioned "staying with a friend in Harrismith". However, in the last note, she indicated travelling on her own to Europe to commence her studies and made no other mention of Van Heerden (G. Steyn n.d. c), despite her and Van Heerden going together.

Gladys's repetition of the erasure of the knowledge of her and Van Heerden's relationship, over and again, written in a shaky longhand, confirms the iterative production of subjectivity, as well as how it can work as a form of epistemic violence. In these notes, written towards the end of her life, she foregrounds her mother Tibbie Steyn instead of Van Heerden. One document has a small note attached with a pin which reads "how with the help of my mother I became an advocate" (G. Steyn n.d. c). The other notes also explicitly speak of how "I went to my mother and asked her to make a plan" (G. Steyn n.d. b) after she passed her examination to become an attorney in South Africa, only to discover that she would not as a woman be allowed to do her articles.

In another note, Gladys scratched out the following: "[M]y mother very kindly" and "I asked my mother whether she could". Finally, she settled on "... and with my mother's consent and help I went over to London to study law" (G. Steyn n.d. a). The latter difficulty in confirming her mother's role reflects the true facts: Tibbie did not approve of her daughter's decision to study Law (Tibbie Steyn [1922] in Truter 1997:170). These repeated erasures are made in the face of the fact that Van Heerden's 
decision to study Gynaecology influenced Gladys to study Law, as Truter (1997:169) also finds.

In 1960, almost two decades after disappearing from public life to farm near Harrismith, Van Heerden re-emerges in Afrikaner nationalist collective consciousness. Her re-emergence is preceded by a flurry of interventions, centred on her sexuality and aimed at preventing this reappearance. Van Heerden's friendships with Van Reenen and Alba Bouwer, assistant editor of popular Afrikaner nationalist women's magazine Sarie Marais, provoked the wrath of Van Heerden's powerful contemporary M.E. Rothmann. For half a century from the 1920s onwards, Rothmann was possibly the most influential amongst Afrikaner nationalist women, working as a journalist and an author; also serving as the sole female member of the Carnegie Commission on the Poor White Problem. In contrast to Van Heerden's destruction of letters, Rothmann as an exemplar of normative Afrikaner womanhood painstakingly archived others' letters with copies of her own to ensure her preservation in Afrikaner historical memory.

For Van Heerden, however, Rothmann wished the opposite. Rothmann's letters document her numerous attempts at preventing Bouwer and Van Reenen from befriending Van Heerden and from recording her life story. She failed, however, as the two younger Afrikaner nationalists aided Van Heerden's re-induction. The fluidity of the 1910s to 1930s, when Afrikaner nationalism expanded its appeal to a diversity of subjects, was over. But Afrikaner nationalism at its triumphant peak in the 1960s again found use for such an exceptional subject as Van Heerden, that is, as demonstration of the vaunted teleological accomplishments of Afrikanerdom. However, even in texts ostensibly aimed at celebrating Van Heerden or restoring her to collective memory, compulsory heterosexuality continues the violence of expurgation. Alba Bouwer (1960) wrote a series of seven Sarie Marais articles, richly illustrated with photos, on "the first Afrikaans woman to become a medical doctor". But Steyn, Heseltine, and Van der Poel are deleted from Van Heerden's life. Male patients are foregrounded to heterosexualise her. Her non-conforming gender presentation is explained as merely practical, that is, the poor roads of the time demanded that a doctor do home visits on horseback and therefore wear pants.

Even in those texts presented as motivated by the desire to reinstate Van Heerden in public memory, her sexuality presents an abomination to remain unmentioned, or to be dismissed. Two texts are notable in this regard: an academic article by Annemarié van Niekerk and "an appreciation" by J.R.L. Forsyth. Van Niekerk (1998:348) questions why Van Heerden "made her mark in history but remained marginalised in the documents of history". She inadvertently provides the answer by omitting any reference to Van Heerden's sexuality. Van Niekerk only rectifies this two decades later as a co-editor of a volume on South African women's writing (Van Beek \& Van Niekerk 2019). The other example seeks to rationalise Van Heerden's 
sexuality. J.R.L. Forsyth (2006:iii) remembered Van Heerden from his childhood years and felt compelled, upon discovering that university libraries draw a blank on her, to provide an "appreciation and a biographical resource" on this "forgotten" but "hugely impressive" woman who "deserves to be remembered". This resource turns Heseltine into "her friend" and makes merely passing reference to Steyn "who had kept house for her in Harrismith" (ibid:i, 17).

On the very last page of his "appreciation", Forsyth grudgingly admits that "it is probably necessary to comment on Petronella's sexuality. Her style of dressing [sic] has already been mentioned" (ibid:29). He proceeds to quote Etienne van Heerden, her family member and an author who based two of his book characters on her, as saying: "She was a dyke but no one said it" (see also De Waal 1998). Another quotation is provided, indicating that she was "an outspoken and openly practising lesbian" (Forsyth 2006:29). Forsyth then spends two paragraphs tracing possible heterosexual "interest" on the part of Van Heerden in her autobiographies, suggesting that she could have been retrieved for heterosexuality if certain life events had turned out differently (ibid:29).

He concludes that "she must have been striking and attractive to people ... sexual orientation is an irrelevance in judging her contribution and impact" (ibid:29). Hence, Forsyth references the figure of the lesbian as a physical abomination, given her failure at femininity, and hopes to rescue his subject as valid by deploying a liberal insistence on ignoring sexual difference. A few sentences later, he muses again that it might be due to "her lifestyle" that "she seems somewhat to have faded away" (ibid:29). He ends on the contradictory note that "she enjoyed her life immensely" (ibid:29).

Turning to the constitution of the archive, the silencing extends to Van Heerden's formal collection of papers. During the 2010s, a section of her papers, which had been in the personal possession of a nephew of hers, was lodged as a discrete collection in the archives at Stellenbosch University (SU), South Africa. Materials shown in the 2013 documentary on Van Heerden (Dreyer 2013) reveal that significant sections of her papers have not been included in the SU collection. These include photographs of Van Heerden and the four women in her life. Van Reenen's archive, which is also housed at SU, seems similarly purged as it contains very little correspondence with Van Heerden despite their close bond from the 1950s to the 1970s. The archive's incomplete status is not explained anywhere, and the selection criteria used to arrive at the truncated collection housed at SU are unclear.

\section{Fact retrieval, or the making of the narratives: "Lost women"}

In the third moment when eliminations are made in history through the processes of silencing, the focus here again homes in on the epistemic violence perpetrated by subjects that serve as Van Heerden's constitutive outsides. That most light is shed, inadvertently, by those most bothered by her, confirms the co-constitutive binary of heterofemininity/lesbianism in subject formation. The narratives that her 
contemporaries formulated, explicate sexual stigmatisation as a primary factor in Van Heerden's eventual hiddenness. The first narrative emerges in the correspondence between Hobhouse and Tibbie Steyn who became fast friends after the former's activism against the British concentration camps in the South African War (from 1899 to 1902).

In letters written between 1917 and 1924, Tibbie expressed her increasing discomfort about the relationship between Gladys Steyn and Van Heerden. Tibbie found Van Heerden "very charming" and indicated that those in her circles, "wish[ed] she [Van Heerden] could be a little different" (Steyn 1917, 1922 in Truter 1997:169). After Gladys joined Van Heerden in Harrismith, they were "living together happily". Calling Gladys "a sweet girl", Tibbie "reconciled to her staying with Nell [Van Heerden] because she seems happy ... I do feel that she is in a way lost and I assure you I often wonder why God made Nell cross Gladdie's path. Surely He has some purpose with a step she took that none of us approved of" (Steyn 1921 in Truter 1997:169). Further light is shed on Gladys' feelings for Van Heerden and how they came to leave Harrismith, contradicting Gladys's elisions in her recounting of this period in her life, as detailed above: "Gladdie has no intention of separating from Nell but she is anxious to qualify in some profession so that she can also earn and do something in life" (Steyn 1921 in Truter 1997:169). While Tibbie wrote frankly about their togetherness in a relationship, she could not name it and instead interpreted it in contrast to heterosexual marriage: "nothing will ever induce [Gladdie] to marry" (Steyn 1922 in Truter 1997:169). That their relationship became increasingly ignominious transpires in Tibbie's statement that it was a step "none of us approved of".

Tibbie's letters to Hobhouse are otherwise replete with heteronormative affirmations in relation to the rest of the family. The letters are to a significant extent dedicated to reporting on various milestones in the iteration of heterosexuality, such as marriage and childbirth. Implicitly, Gladys must have been under immense pressure to end her relationship with Van Heerden, given that "none" of the Steyns "approved" of it. This would be even more the case in the light of Hobhouse's reading of the relationship, which recognises Steyn and Van Heerden's connection even as she disparages it:

\footnotetext{
I understand now, also from what you say, that you feel regretful over Gladys' attachment to Nell v. Heerden. It always appeared to me very strange \& somewhat unusual in S. African life. But you know in Europe it is an everyday matter this coupling up of young women who have struck out for themselves \& do not marry. They find thus the companionship they need \& one usually I notice, takes the more masculine, the other the more feminine role. Thus they secure nearly (not quite) the best of both types of life - having complete independence coupled with companionship which prevents the sinking into the old time 'Old-maidenism'. Nell is to all intents \& purposes a man, or what is called a 'bachelor-woman'. I am surprized that Gladys should therefore now seek to break from what the French call this 'Egoism a deux' and suggest taking up the law.

(Hobhouse 1921: n.p.)
} 
In Hobhouse's interpretation, such a relationship was unusual for South Africa. However, the quotation above shows she also believed it to be unacceptable in Europe where it was common. As typical in homophobic discourse, a heterosexual frame is placed on Steyn and Van Heerden's relationship, focusing on Van Heerden's violation of gender prescriptions for women ("to all intents \& purposes a man"). Hobhouse desexualises the relationship by focusing on its practical but also political implications, arguing that women used such arrangements to achieve independence. Her invocation of "old-maidenism" in the letter could be read as suggesting that women in these relationships avoided this patriarchal categorisation, but has the effect of implicitly suggesting that these women are merely 'old maidens' by another name, again associated with an un-sexual life. While it seems at first as though Hobhouse herself never married - might not be averse to women seeking independence through such an arrangement, the listed associations amount to a disparagement of these relationships.

Apart from hinting that such women are akin to "old maidens", Hobhouse discounted the relationship further by using the term "bachelor-woman" (Hobhouse 1921:n.p.). The use of this term was common at the time to refer to women who remained single, and here serves as a conflation of unmarriedness with singleness in a further dismissal of the relationship. The coup de grace is Hobhouse's use of "Egoism a deux", or 'egotism for two, which insinuates that Steyn and Van Heerden were in fact merely in pursuit of selfish ends. Hence, two women seeking independence in the form of a same-sex relationship are violating a primary aspect of femininity. This aspect is selflessness, of which the normative model of the volksmoeder is a beacon (Van der Westhuizen 2017). Gladys's own mother was politically positioned to be the embodiment of the volksmoeder (see Truter 1997).

The narrative devised here is one of women as selfish if they pursue independence. Van Heerden is presented as a charming interloper who misled 'sweet girls' into egotistical pursuits of professions and women-only relationships, and away from their correct calling of heterosexual marriage. Despite this attempt to show Gladys as 'lost' and without agency in the face of a predatory mannish 'bachelor-woman', Tibbie admitted in a letter written in 1925 that the family's attempts to set Gladys up with men continued to be unsuccessful: "[W]e look at Gladys as the Bachelor Girl” (Steyn 1925). This is several years after Steyn and Van Heerden had separated.

The narrative of Van Heerden as predatory in luring women away from their true calling, rendering them 'lost', surfaces four decades later again in correspondence between Rothmann, Van Reenen, and Bouwer. Van Heerden is othered as a vampiric, evil, and sexually perverse prowler targeting vulnerable women. Rothmann cautioned Van Reenen: "[V]ery glad about the Nell connection. An enriching experience - every now and again: but always interesting" (Rothmann \& Rothmann 1958, emphasis 
added). ${ }^{1}$ Rothmann's daughter Anna was more forthright, writing on the back of the same letter: "Yes, Rykie, you should stay out of that harem of hell. She would gladly bag you". In a letter to Bouwer, Rothmann (1960) elucidated: "Is it that Nell needs such connections to feed her soul? Since I have known her, almost 40 years, she has never been without. To each one she gave much in time and attention and strong assistance and sympathy. Over years to Freddie and Jean. And they clung to her ... It is troubling to see you and Rykie as successors". The last reference to Bouwer and Van Reenen as 'successors' serves as a threat of stigmatisation, should they pursue their associations with Van Heerden.

Rothmann (1959b) elaborated in another letter, also to Bouwer: "[Freddie] is too attached to Nell. Nell has such a hold; but then the captivated person must still become free, like Jean, and continue on own strength ... I don't think Freddie feels that Nell is leaving her on the side for Rykie; she has lived for too long with Nell not to be very familiar with this situation." In yet another letter from Rothmann (1961b) to Bouwer, she described Heseltine as "seeming now more than ever as though she is lost". In the same year, Rothmann (1961a) wrote about Van Heerden's "abnormality that is getting the best of her in old age". If not for that, "her last years, like that of a useful person, would be happy. Her friends she would not have lost; they would have increased". In the same letter, Rothmann made a case for why Van Reenen should "break ties" with Van Heerden, as one "should not allow the abnormal to damage the normal; it is your duty to prevent it where you can"; "it must be prevented ... that [Van Heerden] sinks into contemptibility". Again, the threat was made that Van Reenen could 'sink into contemptibility' if she allowed her 'normality' to be damaged by Van Heerden 'abnormality'.

Given the shift in discourses on lesbianism since the Hobhouse-Steyn exchange, the addition of a pathologising medical parlance ("abnormal") is notable alongside the religious ("evil") and racialising ("harem") elements in the narrative. Whereas the earlier discourse in the 1920s reflects fear and disdain over the effects of surging feminist activism on the hetero-order at the time, the later discourse in the 1960s shows the intersectioning of categorisations of othering (sexuality/race/culture). These categorisations were then imposed by an Afrikaner nationalism newly selfassured in its oppressive hegemonisation of these very elements in the form of apartheid after 1948. The possibility of a sexually agentic woman surrounded by women, and hence not orientated to men, was actively resisted by the deployment of the medico-religious-cultural discourse. Rothmann raised the spectre of Van Heerden sinking into "veragtelikheid", which translates best as "contemptibility" within the context, but is also tellingly synonymous with "abjection".

Rothmann's indication that Van Heerden was no longer "useful" and had lost friends suggests that her concern was with enforcing Van Heerden's abjection. Different 
violences are at work here. The first is the violence in Van Heerden's lifetime, as she had become more isolated, also due to the marginalising actions of detractors such as Rothmann. Apart from this suggestion in Rothmann's letter, Van Heerden wrote a few years later when she was visiting author Etienne Leroux on his farm, that it was "[w] onderful to find people who really seem glad to see one" (Van Heerden ca. 1967). This suggests increasing hostility and social ostracisation. Apart from the violence of isolating Van Heerden, this is also read as an epistemic violence aimed at extinguishing the discursive possibilities for (Afrikaner) women's subjecthood that Van Heerden represented.

\section{The making of history in the 'final' instance: "[0]ne big open v"}

As Trouillot indicates, his frame of four moments of introduction of silences into history is not rigid. The moments are not discrete; they overlap as per the contingencies of human existence and activity. The previous section, applying Trouillot's third moment in history-making - the retrieval of facts to make narratives - could also comprise resistant discourses. Similarly, this section on the 'final' making of history could discuss only the moments of epistemic violence, when Van Heerden's remarkable life and contribution to dissidence are erased in a concluding moment of the making of Afrikaner and South African histories.

However, given that history is never complete, and that contestation is inherent to history-making - and to contribute to the re-remembering and reinstatement of Van Heerden in these histories - narratives of defiance are presented and discussed here as the final moment, using Trouillot's frame. The 'final' moment of history-making is, after all, never completely final despite or perhaps because of the efforts at silencing. Alongside the absences and presences of narratives compiled to stigmatise Van Heerden and render her an unworthy subject for historical retention, Van Heerden's own voice and those of others can be found challenging the dominant storylines, albeit with some difficulty in her own lifetime. A perceptible shift occurs in South Africa's democratic era, when Van Heerden's life is increasingly brought into public memory, both academically and in popular media.

As has been seen, amongst the various modes of silencing, two dialectical approaches by her peers are noticeable: (1) Bouwer and Van Reenen's provisional re-remembering and reincorporation of Van Heerden in Afrikaner nationalist history, with Van Heerden's sexuality notably absent; (2) Rothmann's repeated actions to prevent this reincorporation and eliminate Van Heerden from Afrikaner remembrance, paradoxically by foregrounding her sexuality in pathologising terms - rendering her an illegitimate subject. Both these modes are read here as epistemic violence. Van Heerden as subject and as historical figure is eviscerated. In the first, this evisceration happens in the denial of a central part of her subjectivity in order to negate lesbian subjectivity and knowledges. To aid conformism, the first mode disconnects normatively revered 
accomplishment from lesbian identity. The effect is the suppression of dissidence that problematises Afrikaner nationalist identity, thereby reasserting apartheid hegemony, in this case over white people. In this mode of domestication, Van Heerden's sexuality is completely obliterated from all accounts to reclaim her as a respectable subject and an exemplar of Afrikaner nationalist success.

Bouwer paved the way with the Sarie series of articles, followed by Van Reenen's assistance to Van Heerden in publishing her two autobiographies, and by Van Reenen's (1987) entry on Van Heerden in the Suid-Afrikaanse Biografiese Woordeboek (South African Biographical Dictionary) alongside mostly Afrikaners. In Van Heerden's autobiography, Die 16de Koppie (The 16th Cup), her first-person narrator (1965:146) declares that she would remain a "Nationalist" (NP supporter) until the day she was "cold". The ostensible self-presentation as Nationalist, along with the biographical dictionary entry, later kept this domesticated dissident available for reclamation amid the tumult of the transition to democracy.

In the early 1990s, Afrikaner nationalist historian J.C. Steyn (1991:35) interpreted Van Heerden's Nationalist identification as that "resistance to the party did not mean being unfaithful to the volk". He contended that "[she,] like many Afrikaner nationalists ... did not experience nationalism as an ideology akin to a dogmatic religion but as an attitude to life that could accommodate divergent attitudes and inclinations". Viljoen (2008:191) reads Steyn as merely saying that Van Heerden as a dissident represented one position within a nationalism that "could accommodate varying stances and dispositions". But the effect of Steyn's assertion is here read as Van Heerden being claimed to insist that Afrikaner nationalism can accommodate divergent others. Similar to the 1910s to 1930s, this was an adaptation in the early 1990s to widen Afrikaner nationalism's recruitment net to retain traction amid the vast political changes that democratisation brought.

In the second mode of silencing by peers, exemplified by Van Heerden's Afrikaner nationalist nemesis Rothmann, 'the lesbian' is recognised in order to construe Van Heerden as deeply damaged and damaging, which necessitates her suppression to the point of abjection, lest she upset carefully fabricated Afrikaner and white supremacy. The second mode inadvertently reveals that Van Heerden had fashioned a lesbian life that undermined constructions of lesbianism as confined in victimhood/victimisation (Chauncey, Duberman \& Vicinus 1989). Rothmann's incessant archiving of her writings accidentally allows for details of Van Heerden's loves and life to emerge, frequently in the form of triangular intimate relationships - Van Heerden's "harem", as Anna Rothmann (Rothmann \& Rothmann 1958) would have it. Therefore, while Van Heerden's own official archive was expunged to cut her sexuality from view, bodies in configurations of pleasure peek out elsewhere. Apart from M.E. Rothmann and Anna Rothmann's revealing expressions of consternation about Van Heerden, quoted 
above, the researcher who scours the archives of contemporaries can piece together a picture of a lively lesbian sociality, also in the last two decades of her life.

Van Heerden was intimately befriended with the German couple Freya and Helmuth von Moltke. Helmuth was executed in January 1945 for his role in anti-Nazi resistance, and Freya lived in South Africa afterwards for nine years, spending time with Van Heerden. Helmuth (H. von Moltke 1939) wrote to Van Heerden asking: "Is Jean still in the habit of undressing at [the] table?" Close ties of affinity contain hints of eroticism, such as in Freya's (1957) letter addressed to "Nan, Freddie and Jean" two years after she had left South Africa. Thanking "Nan", as some called Van Heerden, for a gift of gloves. Freya (F. von Moltke 1957) wrote: "Now the whole top of myself is wrapped in Nan's affection and efficiency - if I want it. I cling to the sisterhood!"

This lesbian sociality came to the fore when Van Heerden withdrew from public life. As political dissident, after breaking ranks with the fascist inclined NP in the 1930s, she turned to socialism and explored the opposition to racism (Van der Westhuizen 2020). Her last feminist battle was with the Defence Force's exclusion of female doctors from its Medical Corps in the early 1940s. She became a farmer and disappeared from public life. After the disappointments with the Nationalists and the government liberals, she turned more fully to another community of belonging - an invisibilised community: lesbian but certainly also including heterosexual women with whom some interactions were erotic. She held on to her sexual dissidence, which is why it became the concerted focus of silencing between the 1960s to 1990s. Van Heerden's "harem" was "from hell" because it violated Afrikaner sex, gender and age boundaries and binarisms with its polyamorous inclusions and active sexual expressions. But it also superseded what was understood as sexual, as Freya von Moltke's reference to "the sisterhood" suggests. Contrary to Rothmann's scare-mongering, it also allowed sexual agency, as Freya's reference to "if I want it" indicates.

Van Heerden's challenge to the silencing is also notable in her defiantly feminist autobiographies in the form of "textual slippages" that bring in her sexuality (Smit 2017:2). As has been seen, Van Heerden's relationship with Gladys Steyn was particularly targeted for erasure, including by Gladys herself and by Forsyth even as he professed to restore Van Heerden to remembrance. Gladys Steyn's actions should be read against the tropes that her parents personified within Afrikaner nationalism. Her father, Marthinus, was an active male in male politics up until his death in the mid-1910s. As mentioned, her mother Tibbie was regarded as a model volksmoeder who retained significant cultural influence until her own passing in the mid-1950s. Hence the various incongruent representations of South Africa's first female advocate as someone who exchanged the prestigious position of school principal at a relatively youthful age to become a "housekeeper" for a "friend" in Harrismith for unknown reasons. 
One is further expected to believe that Gladys Steyn's interest and perseverance in entering the daunting male-only world of Law in the 1920s developed in a vacuum, ignoring what her "friend" had just achieved in relation to Medicine. For Van Heerden, in contrast, it was a significant relationship: as noted above, in retrospect as a 75-yearold, she regarded the first period she spent in Harrismith as the happiest time of her life. Her autobiographies feature Gladys Steyn and Heseltine but without explanation as to the nature of these relationships. However, these inclusions by Van Heerden partially filled a gap created by Bouwer in the Sarie series. Van Heerden took it further with the description of one particular scene, mocking heterosexuality while affirming her and Gladys Steyn as sexual beings in relation to each other, including by bringing in physicality. Hers was not a disembodied desire. Van Heerden utilised her second autobiography to describe a scene that followed after a medical call-out in the rural areas around Harrismith that carried on into the evening. Gladys had accompanied her, and they had to rely on the hospitality of a heterosexual farming couple for accommodation that night. In their small home, the couple prepared a makeshift bed for Van Heerden and Steyn to share:

The woman says it has been raining for 14 days and all that she can provide for us to sleep in, are a shirt from [her husband] Dirk and a night shirt of hers ... The woman was thin and frail, and Gladys was hefty in those days. I put on Dirk's shirt. From the front, it does not reach my legs and from the back it hangs below my knees. Gladys is killing herself laughing but when she puts on the night shirt, it won't close. From the middle of her body it is one big open $v$... We very much appreciated the hospitality. Most people were hospitable but not always.

(Van Heerden 1965:109)

Van Heerden's colourful style of narration invokes the scene vividly. The visualisation of the two women, donning the clothes of heterosexuality, only to have their bodies and particularly erogenous zones exposed, is relayed with a celebratory tone. The embodiment is almost palpable. No shame obtains: just simple enjoyment, culminating in the suggestive conjuring of "one big v". This tale and its playful eroticism can be read as a cryptic communication of a lesbian sexuality at ease with itself. Van Heerden rebuts the erasure and pathologisation of lesbianism, presenting instead a discourse of a pleasurable sexuality on her own terms.

It is borne out by comments by the author Cecile Cilliers, a friend of Van Heerden's, in the 2013 Afrikaans television documentary film (Dreyer 2013) on Van Heerden, as part of the series Formidabele Vroue (Formidable Women). The narrative in the film represents the tension between the Bouwer/Van Reenen mode of silencing and a democratic-era recuperation of Van Heerden. This recuperation has mostly taken an academic form (Van der Westhuizen 2020; Van Beek \& Van Niekerk 2019; Smit 2017; Viljoen 2008), with the documentary the only example in popular media, apart from a media interview (De Waal 1998). In the documentary, Van Heerden's cousin Francois van Heerden in interview excerpts insistently presents the Bouwer/Van Reenen 
versions of Van Heerden's life. Forsyth is interviewed making no reference to Van Heerden's sexuality.

But the filmmakers lead with Van Heerden's gender non-conformity, without stigmatisation. Heseltine, obliterated from Van Heerden's own official archive and the most invisibilised despite the longevity of their relationship, features in interviews that provide more details about her life than in any other source found by this author. The documentary ends with a moving rendition by Cilliers of Heseltine's last reflection on Van Heerden's passing, with the effect of restoring Heseltine as an erudite subject, apart from being one of Van Heerden's most significant loves. The filmmakers also feature Cilliers sharing an interaction with Van Heerden, where Cilliers inserts herself as the object of desire after making affirming comments about Van Heerden's lesbian life. Van Heerden had reached over to her and stroked her head, with terms of endearment. Her touch was like an electric current, says Cilliers. Novelist Marié Heese confirms the ménage à trois that existed for some time involving Van Heerden, Heseltine, and Van Reenen. The documentary film serves as the first important step in popular media to restore Van Heerden to public memory as a lesbian subject and fill the silences wrought by the heteronormativity of Afrikaner historiography.

\section{CONCLUSION}

In exploring the epistemic violence perpetrated in the composition of Afrikaner identity, the lens is turned here onto internal gendered and sexual others, homing in on lesbians. Van Heerden is shown as a complex figure who was a political and social, but also a gender and sexual dissident. Trouillot's frame is used of four moments where silences enter the process of making history. Historicisation is understood as a vital form of knowledge, and remembering as crucial to the formation of identities in the present. Hence, the sexual censorship deployed against Van Heerden is understood as an exemplar of how certain options for Afrikaner subjecthood were iteratively shut down.

The chapter shows two modes of silencing: (1) the recuperation of Van Heerden, but with her sexual agency excised; and (2) the exposure of her sexuality as "pathological" to prevent any recuperation of her as historical figure and an exemplar of options for identification. A democratic-era rebuttal of modes (1) and (2) is then discussed, which restores Van Heerden as political and sexual dissident and sexually agentic lesbian. The latter becomes possible in part due to Van Heerden's own resistance to the erasure and stigmatisation of her sexuality. This defiance was enacted through her social practice, as well as in her self-representation in her autobiographies.

"I was a pariah and completely alienated from my family", Van Heerden (1962:67) wrote at the age of 75 . As she embarked on the sea voyage to study Medicine in the Netherlands at the age of 20, she cast into the ocean the referral letters from her parents 
for acquaintances of theirs. She exited the heteropatriarchal order represented by the family. As per the insights of Wittig (1992), lesbian unintelligibility in the dominant episteme of heteronormativity allows for a paradoxical freedom: unrecognisable because their existence excludes men, they can escape the "heterosexual contract" (Wittig 1992).

Lesbian subversion of heteronormativity causes "panic" and "general alarm for an active defence" because of the "repercussions upon straight culture" (ibid:32). This can be read in the reactions to Van Heerden, as discussed above. Her defiance in the face of the epistemic and other violences of Afrikaner heteronormativity created a space of freedom and belonging through lesbian sociality just as apartheid's stranglehold tightened in the 1950s. By repairing the damage of this form of epistemic violence, and re-remembering those internal dissidents, new imaginaries for gendered and sexual others become possible in the present. As Van Heerden (1962:156) declared, staking an agentic claim to authoring her own life: "I am entering a new life and it is mine." 


\section{REFERENCES}

Bouwer, A. 1960. Die Avonture van die Eerste Afrikaanse Vrou wat Geneesheer geword het. Sarie Marais, 13 April, 27 April, 11 May, 25 May, 8 June, 22 June, 6 July.

Brink, E. 1990. Man-made Women: Gender, Class and the Ideology of the Volksmoeder. In: C. Walker \& David Philip (eds.). Women and Gender in Southern Africa to 1945. David Philip: Cape Town.

Chauncey, G., Duberman, M.B. \& Vicinus, M. 1989. Introduction. In: M.B. Duberman, M. Vicinus \& G. Chauncey (eds.). Hidden from History: Reclaiming the Gay and Lesbian Past. Penguin: London. pp. 1-17.

De Waal, S. 1998. The making of myths and stories: Interview with Etienne van Heerden. Mail E Guardian, 10 December, p. 31.

Dreyer, W. 2013. Formidabele Vroue: Petronella van Heerden. Television documentary series. Kyknet/Khaki Productions.

Forsyth, J.R.L. 2006. Anna Petronella van Heerden (26.4.1887-10.1.1975), Doctor, Feminist, Political Activist, Farmer, Archaeologist, Genealogist. An Appreciation and a Biographical Resource. Rosanna: Australia \& J.R.L. Forsyth.

Freedman, E.B. 1998. The Burning of Letters Continues: Elusive Identities and the Historical Construction of Sexuality. Journal of Women's History, 9(4):181-200. https://doi.org/10.1353/jowh.2010.0237

Grosfoguel, R. 2002. Colonial Difference, Geopolitics of Knowledge, and Global Coloniality in the Modern/Colonial Capitalist World-System. Review (Fernand Braudel Center), 25(3):203-224.

Hancock, K. \& Van der Poel, J. (eds.). 1966-1973. Selections from the Smuts papers. Cambridge University Press: Cambridge. https://doi.org/10.1017/ CBO9780511563638

Hobhouse, E. 1921. 'Dearest Mrs Steyn, This week ...' Letter. R.I. Steyn Collection. Archive for Contemporary Affairs, Free State University, 9 October.

Lugones, M. 2007. Heterosexualism and the Colonial/Modern Gender System. Hypatia, 22(1):186-209. https://doi.org/10.1353/ hyp. 2006.0067
Quijano, A. 2000. Coloniality of Power and Eurocentrism in Latin America. International Sociology, 15(2):215-232. https://doi.org/10.1177/0268580900 015002005

Rothmann, M.E. 1961a. 'Liewe Alba, Ons was bly... Letter. A Bouwer Collection. Stellenbosch University, 21 December.

Rothmann, M.E. 1961b. 'Liewe Alba, Baie bly...' Letter. A Bouwer Collection. Stellenbosch University, 6 December.

Rothmann, M.E. 1960. 'Liewe Alba, Baie dankie ... Letter. ME Rothmann Collection. Stellenbosch University, 17 March.

Rothmann, M.E. 1959a. 'Liewe Alba, ek skryf aan jou.' Letter. ME Rothmann Collection. Stellenbosch University, 15 December.

Rothmann, M.E. 1959b. 'Liewe Alba, ek was baie bly. Letter. ME Rothmann Collection. Stellenbosch University, 29 June.

Rothmann, M.E. \& Rothmann, A. 1958. 'Liewe Rykie, ek en Anna. Letter. ME Rothmann Collection. Stellenbosch University, 30 November.

Sherman, L.E. 1998. Unmasking The Heroes: Sources of Power in Afrikaner Mythologising. MA dissertation. University of South Africa: Pretoria.

Steyn, G., n.d. a. 'I started my career as a teacher ...' Autobiographical notes. Gladys Steyn archive, Free State Archives: Bloemfontein.

Steyn, G. n.d. b. 'In June 1922 I was admitted ...' Autobiographical notes. Gladys Steyn archive, Free State Archives: Bloemfontein.

Steyn, G. n.d. c. 'I had resigned as principal'. Autobiographical notes. Gladys Steyn archive, Free State Archives: Bloemfontein.

Steyn, R.I. 1925. 'Dearest Miss Hobhouse...' Letter. R.I. Steyn Collection. Archive for Contemporary Affairs, Free State University, 26 April.

Steyn, J.C. 1991. 'n Gesuiwerde Nasionalis Word Dissident. Tydskrif vir Letterkunde XXIX, p. 24.

Trouillot, M.-R. 1995. Silencing the past: Power and the Production of History. Beacon Press: Boston, MA. 
Truter, E. 1997. Tibbie. Rachel Isabella Steyn 1865-1955, Haar lewe was haar boodskap. Human \& Rousseau: Cape Town.

Van Beek, P. \& Van Niekerk, A. 2019. My Mother's Mother's Mother. South African Women's Writing from 17th Century Dutch to Contemporary Afrikaans. Leiden University Press: Leiden.

Van der Westhuizen, C. 2020. "I am berated as a Communist because I sometimes wear a red tie": Not Forgetting the Awkward Afrikaner, Dr Petronella "Nell" van Heerden. a/b: Auto/Biography Studies, 35(3):771-788. https://doi.org/10.1080/0898 9575.2020.1766209

Van der Westhuizen, C. 2018. (Un)sung Heroines. The Rise and Fall and Rise of the Afrikaner Nationalist Volksmoeder in South Africa. Matatu Journal for African Culture and Society, 50:258-279. https://doi.org/ 10.1163/18757421-05002004

Van Heerden, A.P. 1938a. Fascisme: Italië! Duitsland! Suid-Afrika? Nasionale Pers: Cape Town.

Van Heerden, A.P. 1938b. Waarom Ek'n Sosialis Is. Nasionale Pers: Cape Town.

Van Heerden, P. 1969. Geslagsregister van die Familie van Heerden, 1701-1968. A.A. Balkema: Cape Town.

Van Heerden, P. ca. 1967. 'Sunday 10.10pm Koffiefontein'. Letter. P van Heerden Collection, Stellenbosch University.
Van Heerden, P. 1965. Die 16de Koppie. Tafelberg Uitgewers: Cape Town.

Van Heerden, P. 1962. Kerssnuitsels. Tafelberg Uitgewers: Cape Town.

Van Heerden, P. n.d. 'Ou liefie'. Letter. $P$ van Heerden Collection, Stellenbosch University.

Van Niekerk, A. 1998. A Woman Who Made Her Mark in History but Remained Marginalised in the Documents of History: Petronella van Heerden. Journal of Literary Studies, 14(3-4):348-374. https://doi.org/ 10.1080/02564719808530207

Viljoen, L. 2008. Nationalism, Gender and Sexuality in the Autobiographical Writing of Two Afrikaner Women. Social Dynamics, 34(2):186-202. https://doi.org/10.1080/02 533950802280063

Vincent, L. 1999. The Power Behind the Scenes: The Afrikaner Nationalist Women's Parties, 1915 to 1931. South African Historical Journal, 40(1):51-73. https://doi.org/10.10 80/02582479908671348

Von Moltke, F. 1957. 'Nan, Freddie, Jean, much loved people.' Letter. P van Heerden Collection, Stellenbosch University, 19 December.

Von Moltke, H. 1939. 'Dearest Nan, I am longing...' Letter. P van Heerden Collection, Stellenbosch University, 10 August.

Wittig, M. 1992. The straight mind and other essays. Beacon Press: Boston. 